\title{
Ukeprøva - en sentral, men uutforska teksttype i skolen
}

Tidsskriftet Sakprosa

Bind 10, Nummer 2

(C) 2018

10.5617/sakprosa.5968

T. Flaten og M. Vollan 


\section{Sammendrag}

I artikkelen presenteres karakteristiske trekk ved ukeprøva, som brukes som del av skolens vurderingsarbeid. Ukeprøva er en mye brukt teksttype som er gjenstand for sterk debatt, både i og utenfor skolen. Studien er basert på nærstudium av et materiale som består av 42 ukeprøver, med særlig vekt på innholdsmessige, formmessige og funksjonelle trekk. Resultata av analysen presenteres i to hoveddeler. Først anlegges et heilhetsperspektiv med vekt på gjennomgående fellestrekk der en gjør greie for fire typiske komponenter og tre ukeprøvetyper. Deretter anlegges et fagperspektiv med vekt på interessante funn for hvert av de seks faga som forekommer på ukeprøvene i materialet. Hovedfunnet er at det er ganske stor variasjon når det gjelder form og innhold, men at variasjonen er mindre når det gjelder funksjon. De fleste oppgavene er lukka kortsvarsoppgaver med tydelig kontrollfunksjon. Etter ei kort drøfting av prøvas betydning i skolesammenheng settes ukeprøva som teksttype inn i en videre samfunnssammenheng.

\section{Abstract}

In this article we present the weekly test which is used as a part of the assessment of pupils in primary schools. The weekly test is a much used type of text, and the test is widely debated both within the school and outside. The study object consists of 42 weekly tests, and the study has emphasis on terms of form, content and function. The results of the analysis is presented in two main parts. Firstly we present an overall perspective, where we account for four typical components of the weekly tests and three types of weekly tests. Secondly we look at interesting findings for each of the six subjects that are represented in the material. The study's main findings are that there is great variation in terms of form and content in the weekly tests, while the variation is less in terms of function. Many of the questions in the tests are closed- 
ended questions with an evident control function. After a brief discussion of the importance of these tests in the school context, we discuss the weekly test in a wider context.

Nøkkelord: Ukeprøve, ukeprøvetype, vurdering, kunnskap, danning, profesjonsfellesskap.

Om forfatterene:

Tom Flaten er universitetslektor ved Institutt for nordisk og mediefag, Universitetet i Agder. Magnhild Vollan er førstelektor ved Institutt for nordisk og mediefag, Universitetet i Agder. 


\section{Ukeprøva - en sentral, men uutforska teksttype i skolen}

En liten skolekompis til sønnen vår hvisker i øret til pappaen sin hver torsdag kveld at han dør i magen fordi han skal uketestes i morgen (Nohre-Walldén, 2013).

Med få ord males her bildet av en hjerteskjærende situasjon der skolens testpraksis er tema. Den siterte ytringa, henta fra en kronikk i Aftenposten om kartlegging og testing i skolen, kommer fra en kritisk stemme i debatten om ukentlig testing. Denne debatten engasjerer mange, og gjør seg gjeldende både muntlig og skriftlig, for eksempel i avisenes spalter og på sosiale medier. Men hva er egentlig ukeprøver?

I denne artikkelen presenterer vi en analyse av et utvalg ukeprøver. For å finne svar på spørsmålet om hva som karakteriserer ukeprøva som teksttype, undersøker vi tekstenes form, innhold og funksjon. Dokumentasjon og analyse av ukeprøva som teksttype er vårt hovedanliggende. Ukeprøva hører til i skolekonteksten, og dens pedagogiske rolle er naturligvis også viktig. Vi drøfter derfor hvilken betydning denne teksttypen har for lærer, elever og foresatte som del av skolens vurderingsarbeid. Til sist beveger vi oss utafor skolekonteksten og ser på ukeprøva som element i den store målstyringsdebatten, der ulike samfunnsaktører deltar. Sentralt står da spørsmålet om ukeprøva er et formålstjenlig verktøy i skolen, sett i et samfunnsperspektiv.

\section{Hva veit vi om ukeprøva?}

Ukeprøva er en omdiskutert praksis i skolen, og sammen med andre nyere vurderingsformer har den vært gjenstand for diskusjon, både i lærerkollegier og i det offentlige rom. Det har likevel vært gjort overraskende lite forskning på ukeprøva, både som pedagogisk verktøy og som teksttype. Vi vil her vise til noe av den kunnskapen som kan knyttes til ukeprøva. Det en vil se, er at 
forskning på ukeprøva, i den grad vi finner noe, er en del av forskning på generell vurderingspraksis i skolen, særlig knytta til «vurdering for læring». Dette begrepet er Utdanningsdirektoratets betegnelse på vurdering underveis i opplæringa som skal bidra til å fremme læring.

To større forskningsprosjekter, et fra Nordlandsforskning ${ }^{1}$ og et fra Norges teknisk-naturvitenskapelige universitet (NTNU), undersøkte begge ulike sider ved skolenes praksis etter innføringa av Kunnskapsløftet² i 2006, inkludert vurderingspraksis. Nordlandsforsknings prosjekt «Sammenhengen mellom undervisning og læring» (SMUL), fra 2007 til 2012, var ett av ti prosjekter initiert av Utdanningsdirektoratet under programmet «Evaluering av Kunnskapsløftet». Prosjektet hadde hovedfokus på «hvordan læreren forstår, fortolker og omsetter Læreplan for Kunnskapsløftet3, LKo6, i praksis» (Hodgson, Rønning \& Tomlinson, 2012, s. 11). NTNU-prosjektet «Forskning på individuell vurdering i skolen» (FIVIS), fra 2011 til 2014, skulle «gi et bilde av hvordan vurderingspraksis i norske skoler utvikler seg» (Sandvik \& Buland, 2014, s. 9). Sistnevnte vektla samspillet mellom sentrale føringer eller intensjoner og lokale forståelser og fortolkinger.

Ukentlige prøver er vanlig på barnetrinnet. I kartlegginga, gjort i SMULprosjektet (Hodgson, Rønning, Skogvold \& Tomlinson, 2010, s. 77), av ulike former for underveisvurdering kom det nemlig fram at på småskoletrinnet (1.-4. trinn) sa 8 av de 9 spurte lærerne at de brukte det, mens tallet var 7 av 9 på mellomtrinnet (5.-7. trinn). På ungdomstrinnet (8.-10. trinn) var det mindre vanlig, bare 3 av 20, mens ingen av lærerne i videregående opplæring

\footnotetext{
${ }^{1}$ Nordlandsforskning er et forskningsinstitutt knytta til dagens Nord universitet.

${ }^{2}$ Kunnskapsløftet er en reform i grunnskolen og videregående opplæring, vedtatt av Stortinget i 2004 og innført fra og med skoleåret 2006-07. 3 Læreplanverket for Kunnskapsløftet er den fullstendige betegnelsen for fag- og timefordeling, generell del av læreplanverket, prinsipper for opplæringa og læreplaner for fag.
} 
brukte ukentlige prøver. På høyere trinn blei i stedet periode- eller temaprøver brukt, altså mer tradisjonelle, fagspesifikke prøver knytta til karaktersetting.

De ukentlige prøvene på barnetrinnet hadde ulike navn som «fredagssjekken», «uketest» og «målprøve». Disse ukeprøvene inkluderte flere fag, og målet var altså å sjekke «nokså konkret læringsutbytte i henhold til mål og innhold i gjeldende ukeplan» (Hodgson et al., 2010, s. 71). Ukeprøvene tok maksimalt 20-25 minutt å gjennomføre. Det blei videre pekt på at praksisen med ukentlige, flerfaglige prøver var enkel å gjennomføre sett i lys av at det på barnetrinnet er få lærere involvert i en klasse, og i tillegg var teamarbeid på trinna vanlig, noe som muliggjorde felles ukeplaner og ukeprøver.

Åssen ukeprøvene blei brukt videre av lærerne i vurderings- og læringsarbeidet, gis det ikke noe entydig svar på. Men ettersom ukeprøva blei gjennomført mot slutten av uka, kunne den ikke påvirke kommende ukes ukeplan. Noen av lærerne rapporterte at de brukte ukeprøva til å bedømme elevenes prestasjon, altså «rette» svara. Andre lærere brukte ukeprøva til å gi elevene kommentarer på prestasjonen, mens den tredje bruken av ukeprøvene var å gi elevene konkrete råd om åssen de kunne forbedre seg for å nå læringsmåla (Hodgson et al., 2010, s. 74). Det som imidlertid er tydelig, er at de fleste lærerne hadde endra vurderingspraksis etter innføringa av LKo6. Tre fjerdedeler av lærerne oppga at de hadde endra vurderingspraksis, begrunna med $ø \mathrm{kt}$ formalisering og dokumentasjonskrav i vurderingsarbeidet (Hodgson et al., 2010, s. 85).

Som nevnt ovafor fins det tydelige motforestillinger i offentligheten mot en endra vurderingspraksis som går i retning av økt testing. I sluttrapporten fra SMUL-prosjektet blei det også uttrykt at noen av lærerne «var skeptiske [...] fordi det kunne lede til økt fokus på hva som enkelt kunne testes» (Hodgson et al., 2012, s. 158). I studien av lærernes underveisvurdering fant en nettopp 
eksempler på at «enkelte lærere nesten utelukkende fokuserte på reproduksjon av avgrensede kunnskapselementer i sin interaksjon med elevene» (Hodgson et al., 2012, s. 158).

Utfordringene ved vurdering for læring belyses i SMUL-sluttrapporten gjennom Harry Torrance. Han hevda at «the practice of assessment has moved from assessment of learning, through assessment for learning, to assessment as learning» (Torrance, 2007, s. 281). Torrance skisserte altså at vurderingspraksisen har gått fra vurdering av læring via vurdering for læring til vurdering som læring. Det siste meiner han at kan oppstå med et for ensidig fokus på vurdering som verktøy i undervisninga. Dette beskrives som «en tilnærming preget av performativity, dvs. fokus på overfladisk kunnskap, enkle læringsmål og rask og effektiv kontroll av måloppnåelse» (Hodgson et al., 2012, s. 158). En kan se for seg at ukeprøvene kan bli uttrykk for ei slik tilnærming til vurdering.

Kirsten Sivesind, som oppsummerte flere av forskningsprosjekta knytta til «Evaluering av Kunnskapsløftet», blant anna SMUL, understreka at forskerne var «kritiske til læreres forsøk på å overvåke elevenes læring på barnetrinnet gjennom eksempelvis ukeprøver, hvor lærere fokuserer på relativt avgrensede læringsmål, og deres overfladiske orientering i tilbakemeldingen til elevene» (Sivesind, 2013, s. 380). Videre viste Sivesind til at dette ikke nødvendigvis var et resultat av økt formalisering av læringsarbeidet og nye føringer, men like mye på grunn av «de praksiser som utformes av skolene selv». Spørsmålet er om ukeprøver faktisk er et resultat av myndighetenes målstyring eller om det er ei misforstått tolking som kommer til uttrykk i skolenes praksis.

Det er et mangfold av vurderingspraksiser i skolen, og det er ulikheter både mellom skoler og innad i lærerkollegier, ifølge NTNU-prosjektet FIVIS. Der ville en blant anna prøve å svare på spørsmålet: «Hvilke vurderingspraksiser finnes i norske klasserom?» (Sandvik \& Buland, 2014, s. 9). En fant også her 
ut at ukeprøva var vanlig: «Vi ser at flere skoler bruker såkalte 'ukesluttprøver' i sammenheng med ukeplaner» (Sandvik \& Buland, 2013, s. 102).

Før LKo6 hadde vurdering på barnetrinnet i hovedsak bygd på forståelsen om at «tilbakemeldingene til eleven skulle omfatte elevens framgang og den skulle omhandle arbeidsprosessen» (Sandvik et al., 2012, s. 56). Med økt fokus på målstyring på 1990-tallet og tidlig 2000-tall i nasjonale styringsdokumenter, og ikke minst med innføringa av LKo6, vokste behovet for testing av måloppnåelse fram. Videre viste en til Stortingsmelding4 nr. 16 (2006-2007) ... og ingen sto igjen og pekte på at «departementet var opptatt av at reglementet for individvurdering ikke er tilfredsstillende, og på bakgrunn av denne meldingen blir det satt i gang utprøving av kjennetegn på måloppnåelse» (Sandvik et al., 2012, s. 57). Begrepa «formativ vurdering» og «summativ vurdering» blei sentrale i individuell vurdering, og i rapporten viste en at $\mathrm{i}$ «2006 ble grunnlaget for et helhetlig system for vurdering lagt fram» (Sandvik et al., 2012, s. 58). Behovet for vurderingspraksis av typen ukeprøve hadde dermed oppstått.

At ukeprøver er en vanlig praksis, kan vi også se i andre arbeid. Både Dysthe (2008) og Roen (2015) pekte på ukeprøver som en utbredt vurderingspraksis. Dysthe sa om ulike former for oppsummerende vurdering at «[i] mange barneskuleklasser er Fredagssjekken eit fast innslag» (Dysthe, 2008, s. 21). Roen (2015) viste at begge skolene hun hadde undersøkt, brukte ukeprøver som ett av flere verktøy for å arbeide med og sjekke at elevene hadde forstått nye naturfagsbegrep.

\footnotetext{
4 Ei stortingsmelding er et dokument som Stortinget får fra regjeringa. Det kan være meldinger om planer som regjeringa vurderer å sette i verk og som den ønsker å få drøfta i Stortinget, for eksempel med tanke på framtidig lovgiving.
} 
Det interessante ved de ulike forskningsarbeida som omtaler ukeprøver, er at ukeprøvene i disse studiene bare var en liten del av en større heilhet, oftest knytta til vurdering. Ukeprøvene nevnes ofte bare i ei bisetning, og alltid heilt kortfatta. Ingen av studiene har gått spesifikt inn på ukeprøvene for å undersøke dem nærmere, verken pedagogisk eller tekstlig.

Et anna sted vi finner ukeprøver omtalt og diskutert, er ved fylkesmennenes 5 tilsyn av skoler. I flere av disse tilsyna kommenteres bruken av ukeprøver som ett av flere verktøy for vurdering. I et tilsyn utført av Fylkesmannen i Buskerud (2015) blei det pekt på at det på den aktuelle skolen blei brukt «uketester» både til vurdering og til å gi veiledning om åssen eleven kunne øke sin kompetanse. Uketestene blei brukt sammen med flere andre vurderingsverktøy. Fylkesmannen meinte det var en uheldig praksis at det var opp til trinnteam eller den enkelte lærer å avgjøre åssen de ulike vurderingsverktøya blei brukt.

Vi finner også ofte ukeprøver omtalt i lokale planer i skoler og kommuner. Dette er med på å underbygge at ukeprøver er en nokså vanlig praksis. I sørlandskommunen Birkenes nevnes ukeprøver i Handlingsplan for Birkenesskolen 2014-2018 (Birkenes kommune, 2014). I handlingsplanen nevnte to av kommunens skoler ukeprøver, da kalt henholdsvis «uketest» og «ukesjekk». Begge skoler trakk dem fram under «Hva er bra?». Disse to skolene opplevde at ukeprøver var en god praksis, og ønska å fortsette med dem.

5 Fylkesmannen er regjeringas nærmeste representant i fylket og skal påse at Stortingets og regjeringas vedtak gjennomføres. 


\section{Ukeprøva som kontrovers}

Som nevnt var ukeprøva de fleste steder ei nyvinning som kom med økt vekt på målstyring, innføringa av LKo6 og fokuset på vurdering for læring. Særlig målstyringa i skolen har ført til stor debatt. Ukeprøvene er en del av målstyringsdebatten, slik sitatet i innledninga av artikkelen illustrerer, men samtidig bare en liten del av den. Det er ikke mulig å gi ei fyllestgjørende utgreiing om ordskiftet rundt målstyring her. Vi vil likevel gi noen eksempler fra debatten hvor ukeprøvene er nevnt, for å belyse ukeprøvas stilling som del av en omdiskutert praksis i skolen.

Simon Malkenes har vært en av Oslo-skolens ${ }^{6}$ synligste kritikere de siste åra . Han har retta skarp kritikk mot det han oppfatter som en markedsstyrt skole som søker raske, målbare resultater. Ukeprøvene er eksempel på det han meiner er en feilslått skolepolitikk. I en kronikk pekte Malkenes (2015) på at «[i] styringssystemet i Osloskolen fungerer de standardiserte prøvene, og for eksempel ukeprøver hver fredag, som sluttvurderinger (summativ vurdering)». Malkenes hevda at prøvene ikke lenger fungerte som underveisvurdering, hvor elevens videre læring sto i fokus, men utelukkende som dokumentasjon for læreren til blant anna skriftlig halvårsvurdering. Osloskolens testregime er mer omfattende enn i de fleste andre kommuner sjøl om byrådsskiftet i 2015 har dempa testkrava noe.

Duesund (2011) fra Utdanningsetaten i Oslo viste til praksisen med «ukesjekker» som viktig for tilpassing og videre planlegging av undervisning. I tillegg kunne ukeprøvene være en del av lærernes dokumentasjon av læringsarbeidet. Tidligere utdanningsbyråd Anniken Hauglie i Oslo begrunna fokuset på mål og tester på følgende måte: «Jeg mener tett oppfølging av

${ }^{6}$ Betegnelsen «Oslo-skolen» brukes om skolene i Oslo kommune. 
barna og oversikt over deres utvikling skaper trygghet for elever og foreldre» (Ertesvåg, 2015). Ukeprøva kan være et verktøy for å gi denne oversikten.

På landsbasis er det likevel motstanderne av målstyring og slik vurderingspraksis som er de mest vokale og synlige. Organiserte grupper som Foreldre mot målstyring og Foreldreopprør i Osloskolen er til dels svært aktive, og deres kamp uttrykkes blant anna i sosiale medier som Facebook. Det har ofte vært sterke ord i debatten, slik sitatet i innledninga er et eksempel på. Debatten har særlig vært knytta til målstyring og testpraksis i Oslo-skolen, men som vist ovafor er den også gyldig for resten av landet.

\section{Et blikk på kunnskap og danning}

Før vi presenterer materialet og analysen av det, tar vi opp noen teoretiske perspektiver på kunnskap og danning. Disse perspektiva trekker vi så inn i tolkinga av resultata. Vi tar utgangspunkt i Per Inge Båtnes' modell for studiet av lærebøker (Båtnes, 1995). I denne modellen identifiserer han tre danningsideal som han omtaler som normsettere for kunnskapsformidling.

Det første danningsidealet er det formative. Her er målet å forme atferd gjennom ferdighetstrening og etterlikning etter normative modeller. En øver inn visse prosedyrer som repeteres heilt til de er automatisert. Denne danninga gjelder ferdighetsbetont kunnskap. Til det formative danningsidealet hører et kunnskapsideal der eleven skal lære å huske, repetere og sitere. Det andre danningsidealet er det figurative. Det henger tett sammen med den ensyklopediske tradisjonen, der målet er å lære et innhold som formidles gjennom skriftlig informasjon, med vekt på begrep og figurer. Her vurderes det Båtnes kaller «informasjonskapasitet» og «evnen til analytisk handling med begreper» (s. 99), høyest. Til det figurative danningsidealet hører et kunnskapsideal der eleven kan motta informasjon og så sortere, analysere og dokumentere den. Det tredje danningsidealet er det operative. 
Her vektlegges betydninga av å utvikle evnen til å lage en enhet av lærestoffet og egne erfaringer. Eleven skal gjøre lærestoffet til sitt eget gjennom å engasjere og involvere seg, og å være kritisk vurderende i møte med ny informasjon.

De tre ideala sier i ulik grad noe om mål for arbeidet med skolefaga. I noen fag legges det stor vekt på å øve på ferdigheter, mens andre er mer begrepsorienterte. Enkelte fag kan ha mål som kan kategoriseres som både formative, figurative og operative. Dette henger sammen med at det ligger ulike typer kunnskap bak de ulike skolefaga. «Det er viktig at man som lærer er klar over at ulike fag på grunnleggende måter faktisk er forskjellige», uttalte naturfagdidaktikeren Svein Sjøberg i ei utgreiing om skole, kunnskap og fag (Sjøberg, 2001, s. 27).

\section{Materialet og metoden}

Som gjennomgangen ovafor har vist, er ukeprøva en sentral, men uutforska teksttype i skolen. I denne artikkelen ønsker vi særlig å belyse hva som karakteriserer ukeprøva som teksttype. Materialet vårt består derfor primært av ukeprøver. Begrepet «ukeprøve» brukes her om ei prøve som omfatter spørsmål fra to eller flere fag, og som gjennomføres med jevne mellomrom, normalt mot slutten av hver uke. Konkret består materialet av 42 ukeprøver brukt på 3.-7. trinn. Disse kommer fra ni skoler i fem fylker. Fra noen skoler har vi mottatt ukeprøver som er brukt på ett trinn, mens andre skoler er representert med ukeprøver brukt på to eller tre trinn. 


\begin{tabular}{|l|l|l|l|l|l|}
\hline & 3. trinn & 4. trinn & 5. trinn & 6. trinn & 7. trinn \\
\hline Antall ukeprøver & 5 stk. & 16 stk. & 17 stk. & 2 stk. & 2 stk. \\
\hline
\end{tabular}

Tabell 1: Materialet fordelt på trinn

I tillegg inngår 17 ukeplaner som korresponderer med 17 av disse ukeprøvene, i materialet.

Opprinnelig ønska vi å få tilgang til et breiere utvalg ukeprøver og korresponderende ukeplaner. Først orienterte vi oss på nettsidene til grunnskoler spredd utover heile landet. Noen steder kom det tydelig fram at ukeprøver var i bruk skoleåret 2016-17, mens det andre steder var mer tvetydig eller ikke spor av slik bruk. Deretter gjorde vi et tilfeldig utvalg blant skoler der informasjonen indikerte bruk av ukeprøver, og henvendte oss per epost til rektor ved én skole i hvert fylke med spørsmål om hjelp til å skaffe til veie et materiale som besto av tre ukeplaner og ukeprøver fra samme uke for to nærmere definerte klassetrinn.

Å få tilgang til et slikt materiale viste seg å være krevende på flere måter. Enkelte skoler svarte umiddelbart nei på henvendelsen fordi skolen ikke brukte ukeprøver lenger. Noen rektorer uttrykte skepsis mot vurderingsforma og hadde aldri tillatt bruk av ukeprøver. Andre svar kan tolkes dit hen at skolens ledelse ikke var interessert i å dele denne informasjonen med forskere, kanskje fordi ledelsen ikke har innsyn i eller «kontroll» med denne delen av skolens praksis. Vårt inntrykk er at utarbeiding og lagring av både ukeplaner og ukeprøver mange steder er noe kontaktlærer(e) på det enkelte trinnet tar seg av, og at disse tekstene nærmest er uttrykk for en privat praksis. Dette inntrykket har festa seg siden flere rektorer som ønska å skaffe til veie det etterspurte materialet, brukte noe tid på kontakt med lærerne på trinna før de kunne sende sitt bidrag. 
Storparten av materialet er henta fra 4. og 5. trinn. Her er det stor geografisk bredde siden alle de ni skolene er representert med ukeprøver brukt på begge eller ett av disse trinna. Studien er derfor i hovedsak konsentrert om ukeprøvene på 4. og 5. trinn, og de fleste eksempla er henta herfra. Når det gjelder spørsmålet om hva som karakteriserer ukeprøva som teksttype, har vi undersøkt formmessige forhold, og videre har vi kartlagt og analysert innholdsmessige forhold. Ukeplaner fra 4. og 5. trinn er brukt som støtte i arbeidet med tilhørende ukeprøver, idet vi ser på den innholdsmessige sammenhengen mellom ukeplanene og ukeprøvene der det er naturlig. Vi går ikke nærmere inn i ukeplanene i denne studien. Underveis i analysen av ukeprøvene ser vi også på ulike funksjoner som kommer fram der.

For nærmere å forklare hva vi tenker om begrepa «innhold», «form» og «funksjon», kan det være naturlig å koble dem med tankene bak skrivetrekanten som blei utarbeidd i SKRIV-prosjektet (Smidt, 2010).

Skrivetrekanten er et didaktisk hjelpemiddel som skal illustrere sammenhengen mellom innhold, form og formål ved elevskriving. I møte med elevene er disse begrepa bytta ut med spørreorda «hva», «hvordan» og «hvorfor». Innhold er altså hva teksten handler om, form handler om hvordan teksten ser ut, mens formål handler om hvorfor teksten er skrevet, altså intensjonen med teksten.

For oss betyr dette at vi med «innhold» meiner det fagstoffet ukeprøva dreier seg om, for eksempel hvilke fag elevene spørres om, og hvilke oppgavetyper som brukes. Med «form» meiner vi det observerbare oppsettet og ulike tegnsystem. I denne sammenhengen tenker vi altså for eksempel på hvilke deler ukeprøva består av, og hvilke modaliteter som brukes. Med «modalitet» meiner vi her ulike tegnsystemer som er med på å skape meining i teksten. Når det gjelder «funksjon», ser vi på formålet med ukeprøva, for eksempel som underveisvurdering og kontaktarena. 
Resultata presenteres i to hoveddeler. Først anlegger vi et heilhetsperspektiv på ukeprøvene, med vekt på gjennomgående fellestrekk og tydelige ulikheter. Her presenterer vi sentrale funn i form av ukeprøvetyper med faste og frie komponenter. Deretter skifter perspektivet fra heilhet til fag. I denne delen gjør vi greie for interessante funn for hvert enkelt fag, både når det gjelder forekomst, form og innhold.

Som tekstforskere er vi påvirka av kritisk diskursanalyse, og vi anser det som viktig å være mer enn bare dokumenterende og deskriptive i vår framstilling. Skrede (2017, s. 21) understreker at kritisk diskursanalyse er en breiere tekstanalyse som også «undersøker hvilke ideologiske interesser tekster kan tenkes å tjene». Vi velger derfor til slutt å drøfte ukeprøvene både som del av skolens vurderingsarbeid og som del av samfunnsdebatten om skolen.

\section{Heilhetsperspektiv på ukeprøvene}

I materialet finner vi flere typiske trekk ved ukeprøvene, og nedafor presenterer vi resultata av overordna observasjoner. Først gjør vi greie for gjennomgående fellestrekk slik de kommer til uttrykk gjennom fire komponenter: tre faste og én fri. Deretter presenterer vi tre ukeprøvetyper i form av typiske eksempler for å vise tendenser i materialet.

\section{Faste og frie komponenter}

Den første faste komponenten finner vi øverst på alle ukeprøvene i form av ei samling av informasjon. Den består som regel av tittel på ukeprøva, ukenummer eller dato, klassetrinn samt plass for eleven til fylle inn sitt navn. Disse enhetene utgjør det en kan kalle ei klynge («cluster») (Baldry \& Thibault, 2005). Med denne klynga gis en felles introduksjon til ukeprøva, og elementa i den behandles som en heilhet av eleven. I eksempel 1 ser vi ei typisk informasjonssamling. 


\section{MÅLPRøVE UKE 4 NAVN}

Eksempel 1: Samling av informasjon

I eksempel 2 ser vi en annen komponent som framstår som nærmest fast. Det dreier seg om «sett»-kolonne og poengskår. Mer enn halvparten av ukeprøvene har med en «sett»-kolonne hvor foresatte skal skrive under. Slik formaliseres kontakten mellom skolen og heimen. I tillegg finner vi en egen kolonne for poeng eller resultatboks i en tredjedel av ukeprøvene.

\begin{tabular}{|c|c|}
\hline $\begin{array}{l}\text { Resultat: } \\
\qquad / 23 p\end{array}$ & Underskrift: \\
\hline
\end{tabular}

Eksempel 2: Kolonne for resultat og underskrift

Mens de to omtalte komponentene kan sies å gjelde form, er den tredje faste komponenten direkte knytta til innhold. Denne komponenten står like under den første på alle ukeprøvene i materialet, og består av faglige oppgaver. Halvparten av ukeprøvene har med oppgaver fra tre fag, mens den andre halvparten fordeler seg jevnt mellom ukeprøver med to og fire fag. Kun éi prøve har med oppgaver fra fem fag. En kunne tenke seg at antall fag representert på ukeprøvene ville øke eller minke oppover på trinna, men det er ingen klare tendenser til det i materialet. En kunne videre tenke seg at oppgavene ville endre seg oppover på trinna, slik at det for eksempel blei større rom for oppgaver av mer analyserende karakter. I vårt materiale er det imidlertid kontrollspørsmåla som dominerer på alle trinna. Når en ser nærmere på hvilke fag som er representert på ukeprøvene, skiller tre fag seg ut som de vanligste. Det er norsk, matematikk og engelsk. Norsk er med på nesten alle ukeprøvene, mens det er spørsmål om matematikk og engelsk på 
omtrent tre av fire ukeprøver. Det er med andre ord de store, skriftlige faga som dominerer.

En del ukeprøver omfatter en fri komponent i tillegg til de tre faste. På ti av ukeprøvene kommer det ei ny gruppe spørsmål etter fagspørsmåla. Det er spørsmål om psykososiale forhold, som åssen den siste uka har vært med hensyn til trivsel og venner. Noen av spørsmåla gjelder også elevenes læringsarbeid. Det kan være spørsmål om hva de konkret har lært, og om mulige forbedringer neste uke. I eksempel 3 ser en at det stilles flere spørsmål av denne typen i samme ukeprøve. Spørsmål 2 her vil kunne tolkes som å handle om både læring og trivsel.

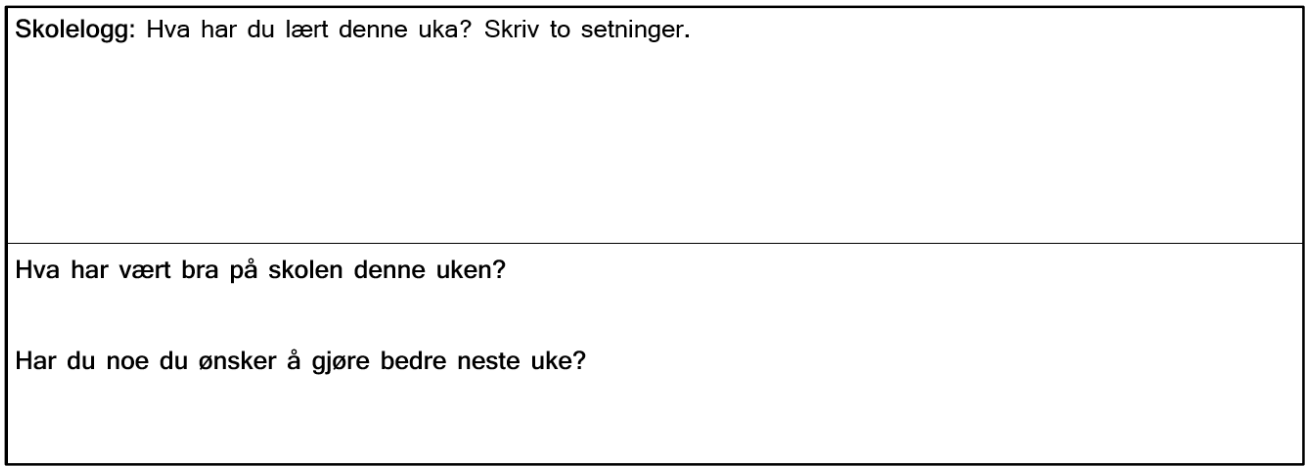

Eksempel 3: Spørsmål om læring og psykososiale forhold

I tillegg til slike spørsmål om egen læring legges det på andre ukeprøver opp til egenvurdering. Totalt har 10 av de 42 ukeprøvene med ei form for egenvurdering. Det dreier seg da om avkryssingsbokser hvor eleven skal krysse av for i hvilken grad en har forstått eller gjort god nok innsats. I eksempel 4 etterspørres elevens egenvurdering av innsatsen med leksene. 
Sett kryss ved den setningen som passer best.

Jeg har jobbet det beste jeg kan med leksene. Jeg har ikke jobbet så godt jeg kan med leksene.

Eksempel 4: Egenvurdering

Spørsmåla som inngår i den frie komponenten, er ikke fagspørsmål. Slik vi ser det, dreier det seg først og fremst om en kontaktfunksjon. Likevel kan det tenkes at noen elever kanskje vil oppleve spørsmåla i eksempel 4 som kontroll. Eleven skal gi uttrykk for sin opplevelse av å være på skolen og reflektere over egen innsats med skolearbeidet. Slik får læreren nyttig informasjon om den enkelte eleven. Denne frie komponenten åpner for å styrke kontakten mellom elev og lærer.

\section{Ukeprøvetyper}

Fra materialet har vi valgt ut tre ukeprøver som representerer typer av ukeprøver. Disse ukeprøvetypene viser særlig noe av den innholdsmessige og formmessige variasjonen i materialet. De tre typene er ulike når det gjelder modalitetsbruk og hvilke spørsmål som stilles. Til grunn for inndelinga ligger flere perspektiver, og det er ikke slik at de tre typene gir et fullstendig bilde av materialet.

\section{Ukeprøvetype 1: Den minimalistiske ukeprøva}

Denne ukeprøvetypen har et svært enkelt oppsett med begrensa bruk av modaliteter, den er uten illustrasjoner og som regel gjennomført i svart-hvitt. Den stiller relativt avgrensa fagspørsmål og er lite omfangsrik. Type 1 illustreres i eksempel 5 gjennom ei ukeprøve som omfatter kun de tre vanligste faga. I eksempelet er bare to av tre faste komponenter med. 


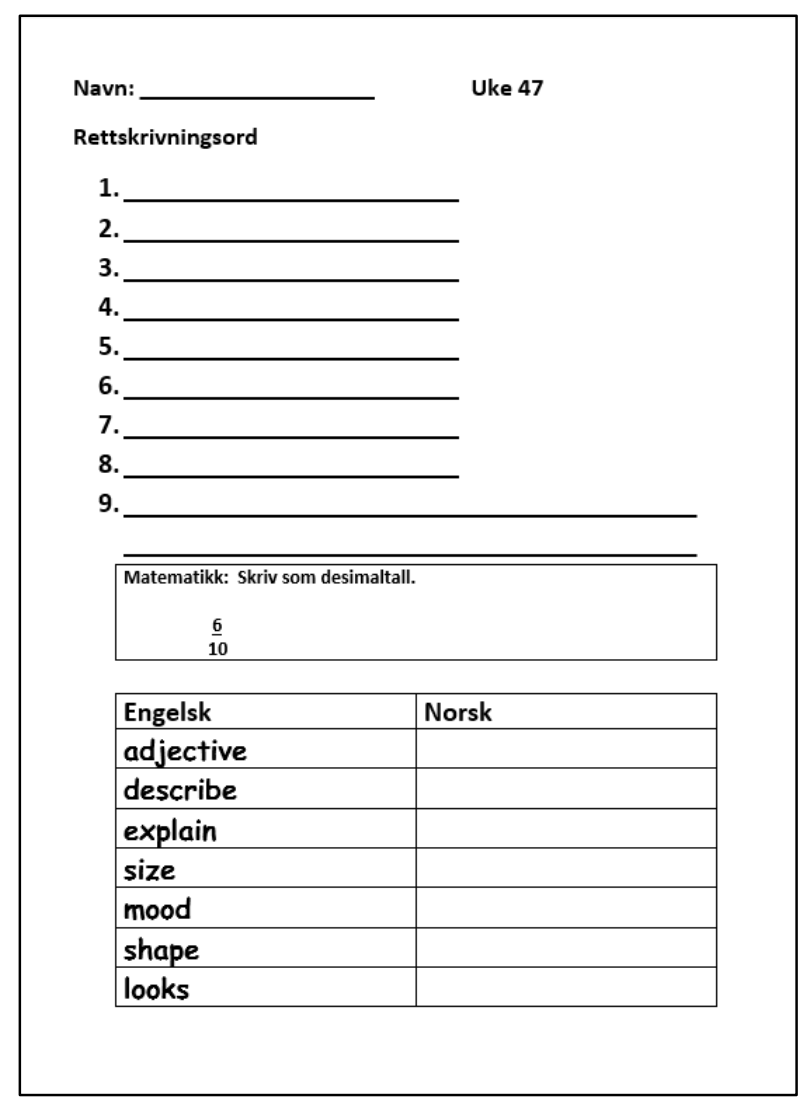

Eksempel 5: Ukeprøvetype 1 (4. trinn)

\section{Ukeprøvetype 2: Den komplekse ukeprøva}

Denne ukeprøvetypen er i langt større grad multimodal. Den består gjerne av flere illustrasjoner og kan ha en aktiv fargebruk. Den stiller ofte flere og mer omfattende fagspørsmål. Bruken av flere modaliteter åpner i tillegg for mer variasjon i oppgavene. Den er altså mer kompleks både i form og innhold enn type 1. Type 2 illustreres i eksempel 6 gjennom ei ukeprøve med spørsmål fra fire fag: de tre store faga og KRLE (kristendom, religion, livssyn og etikk). I eksempelet er det dessuten med vurderingskolonne med plass til poengskår. Denne ukeprøva består altså av alle de tre faste komponentene. 


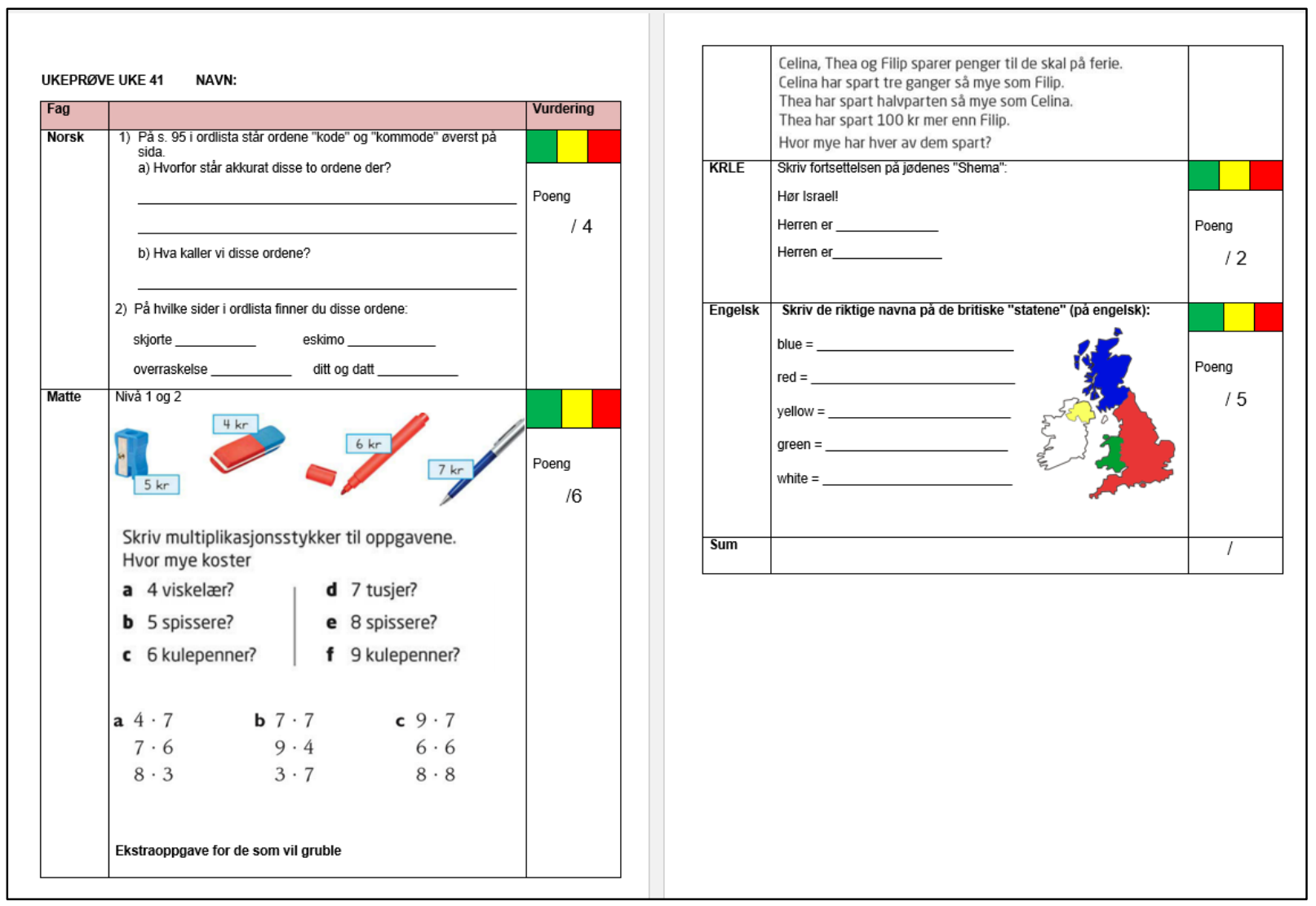

Eksempel 6: Ukeprøvetype 2 (5. trinn)

\section{Ukeprøvetype 3: Den utvida ukeprøva}

Det spesielle ved denne ukeprøvetypen er at den omfatter både fagspørsmål og psykososiale spørsmål. Den har en utvida funksjon sammenlikna med type 1 og 2, som er reint faglige ukeprøver, ved at den også inneholder kontaktfunksjoner. Når det gjelder formmessige forhold, kan type 3 ha fellestrekk med de to andre. Type 3 illustreres i eksempel 7 gjennom ei ukeprøve med innslag av ulike modaliteter og relativt avgrensa spørsmål fra flere fag, etterfulgt av spørsmål om skoleuka og kamerater. Denne ukeprøva består med andre ord av de tre faste komponentene og dessuten den frie komponenten. 


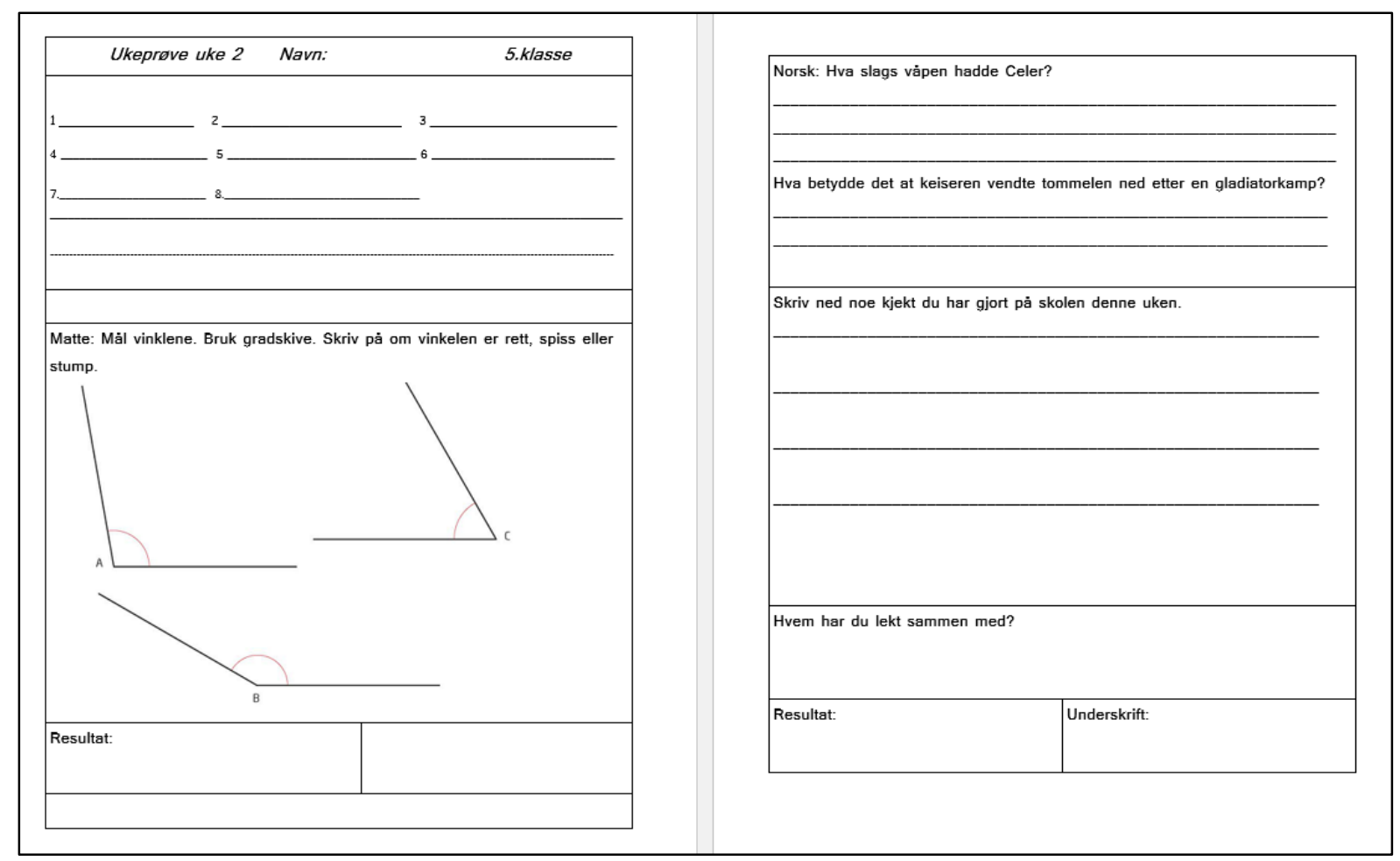

Eksempel 7: Ukeprøvetype 3 (5. trinn)

\section{Fagperspektiv på ukeprøvene}

Som nevnt spørres det altså om norsk, matematikk og engelsk på de fleste ukeprøvene i materialet. I tillegg er naturfag, samfunnsfag og KRLE representert på en mindre del av ukeprøvene. I tabell 2 presenteres tall for hvor mange ukeprøver på hvert trinn som omfatter spørsmål fra disse seks faga. 


\begin{tabular}{|c|c|c|c|c|c|c|}
\hline $\begin{array}{l}\text { Trinn og } \\
\text { antall prøver }\end{array}$ & $\begin{array}{c}\text { 3. trinn } \\
5\end{array}$ & $\begin{array}{l}\text { 4. trinn } \\
16\end{array}$ & $\begin{array}{c}\text { 5. trinn } \\
17\end{array}$ & $\begin{array}{c}\text { 6. trinn } \\
2\end{array}$ & $\begin{array}{c}\text { 7. trinn } \\
2\end{array}$ & $\begin{array}{l}\text { samla } \\
=42\end{array}$ \\
\hline norsk & 5 & 15 & 16 & 2 & 2 & $=40$ \\
\hline matematikk & 4 & 12 & 14 & 2 & 2 & $=34$ \\
\hline engelsk & 5 & 12 & 11 & & 2 & $=30$ \\
\hline naturfag & 1 & 3 & 5 & & & $=9$ \\
\hline samfunnsfag & 1 & 2 & 6 & & & $=9$ \\
\hline KRLE & 3 & & 2 & & 1 & $=6$ \\
\hline
\end{tabular}

Tabell 2: Fagrepresentasjon fordelt på trinn

Videre gjør vi greie for interessante funn for de seks faga, i den rekkefølgen de står i tabellen. De tre første får brei omtale med flere eksempler siden de er så rikt representert i materialet. Når det gjelder de øvrige faga, omtales de mer kortfatta. Etter at oppgavene i hvert av faga er omtalt, går vi kort inn på flerfaglige oppgaver.

\section{Norsk}

På 40 av 42 ukeprøver er det éi eller flere norskfaglige oppgaver. Som regel kommer de norskfaglige utfordringene først på prøva, men på prøver med flere norskspørsmål er de gjerne plassert mellom spørsmål fra andre fag. Oppgavetypen orddiktat dominerer, den forekommer på 31 ukeprøver i alt. Orddiktaten har en klar sammenheng med øveorda som står på ukeplanen, og kontrollerer elevens rettskrivingsferdighet. Antall øveord og diktatord varierer og ligger i spennet mellom fire og ti. På en ukeplan for 5. trinn finner vi fem øveord som vist i eksempel 8. 


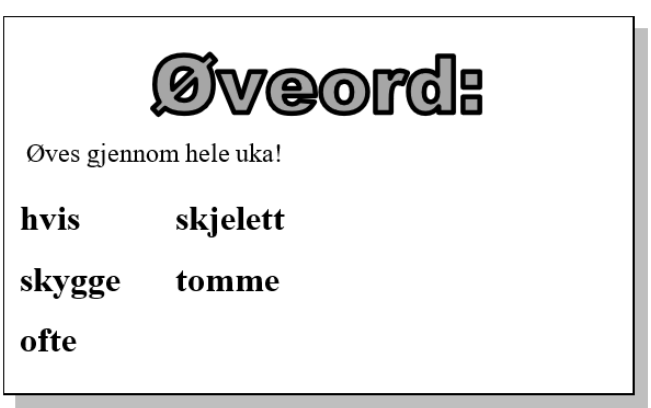

Eksempel 8: Norsk, 5. trinn

Det er som nevnt flere norskfaglige spørsmål på noen ukeprøver. Temaet kan være grammatikk, som på ei ukeprøve for 4. trinn med to større oppgaver om ordklassen substantiv. Først skal elevene streke under alle substantiva i fem setninger, deretter skal de markere egennavn og fellesnavn med ulik farge i ei ordsamling. Det kan også være spørsmål som handler om å forklare (fag)ord og faste uttrykk. I noen tilfeller dreier det seg om ord som inngår i en ordbank elevene har arbeidd med i løpet av uka.

Tekstrelaterte spørsmål er spørsmål om skjønnlitterære tekster eller saktekster elevene skal ha lest. Eksempel 9 og 10 viser slike spørsmål.

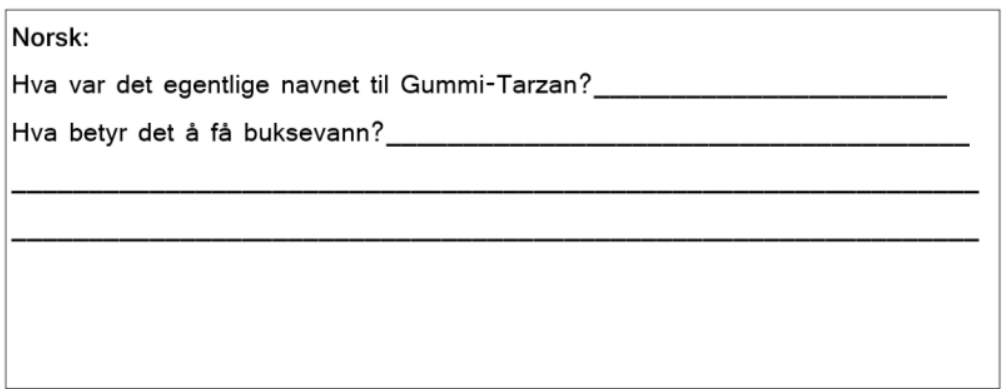

Eksempel 9: Norsk, 5. trinn 


\begin{tabular}{|l|}
\hline Norsk \\
Hva er en mottaker? \\
Hva er en avsender? \\
Hva kjennetegner et formelt brev? \\
\hline Hva kjennetegner et uformelt brev? \\
\hline Skriv ned tre forskjellige måter å kommunisere på.. \\
\hline
\end{tabular}

Eksempel 10: Norsk, 5. trinn

Mange av norskspørsmåla er lukka, det vil si at svaret er gitt. Når det gjelder orddiktater og grammatikkoppgaver, er svara enten korrekte eller ukorrekte, og oppgavene åpner ikke for alternative svar. Ordforklaringsspørsmål vil oppleves som mer åpne siden eleven kan bruke egne ord, men innholdet $\mathrm{i}$ svaret må likevel være innafor det som er allment akseptert. Det fins også åpne norskfaglige spørsmål. Det siste spørsmålet i eksempel 10 kan forstås slik, men plassen å skrive svaret på er svært begrensa, så eleven kan i liten grad skrive utdypende.

Når det gjelder modalitetsbruken i de norskfaglige delene i materialet, preges den av mange fellestrekk. Orddiktatene skal som regel skrives inn i tabell eller på nummererte linjestumper (se eksempel 5). Andre oppgaver er satt i rammer, gjerne med ei eller flere stipla linjer som indikerer hvor omfattende svar som forventes. På ei prøve for 5 . trinn utfordres eleven til å studere et bilde for å finne og skrive ned minst sju verb. Dette er eneste forekomst av bildebruk i norsk.

\section{Matematikk}

På 34 av 42 ukeprøver stilles det ett eller flere matematikkspørsmål. Ofte kommer disse spørsmåla tidlig på prøva, som nummer to eller tre. Blant de 
vanligste oppgavene kan nevnes addisjons-, subtraksjons-, divisjons- og multiplikasjonsoppgaver.

Videre finner vi geometrioppgaver der elevene på 5. trinn skal navngi geometriske figurer, og oppgaver der de skal måle sider på ulike figurer og regne ut omkrets og areal. Innafor dette temaet er oppgavene av ulik vanskegrad. På ei prøve skal elevene først forklare «hva som er typisk med disse figurene: parallellogram, trapes, kvadrat, likesida trekant, rettvinkla trekant og likebeina trekant». Deretter skal de tegne alle figurene.

På ei prøve for 4. trinn skal elevene gjennom ulike oppgaver vise forståelse for koordinatsystemet, mens elever på 5. trinn skal lese et søylediagram og svare på spørsmål om dette. Enkelte oppgaver er begrepsorientert, blant anna er oppgavene på ei prøve knytta til begrepa «partall», «oddetall» og «primtall». Som svar skal elevene gi eksempler, de skal altså ikke forklare begrepa.

Noen oppgaveformuleringer er svært kortfatta og forma som en instruks, som vist i eksempel 5. I materialet finner vi også klassiske tekstoppgaver, som vist i eksempel 11.

\footnotetext{
Matte: Forholdsregning:

I en oppskrift er forholdet mellom sukker og mel $1: 3$

Stian har 450 gram sukker som han skal bruke opp. Hvor mye mel trenger han?
}

\section{Eksempel 11: Matematikk, 7. trinn}

De fleste matematikkoppgavene er lukka, og elevene skal finne fram til riktig svar. På ei ukeprøve for 7. trinn skal elevene først finne svaret på ei regneoppgave og deretter lage ei passende tekstoppgave. Slike oppgaver gir elevene ei åpen utfordring der svara kan bli svært ulike ut fra hva de trekker inn i oppgaveformuleringa si. 
Når det gjelder modalitetsbruken, preges den av variasjon. På noen ukeprøver er det fargerike figurer i geometridelen, mens oppgavene i de fire regneartene noen steder er formulert slik at elevene sjøl skal sette opp regnestykka, andre steder er det bare å fylle inn svaret. Oppgaver i gangetabellen kan være satt opp i tabellform. I matematikkdelen inngår det med andre ord ofte ulike figurer og noe fargebruk. I materialet finner vi også ett tilfelle av bildebruk, vist i eksempel 12.

\section{Matematikk}

3. Rund av til nærmaste tiar og finn summen av varene:

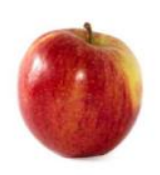

$14 \mathrm{kr}$

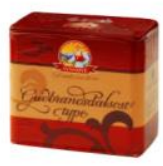

$78 \mathrm{kr}$

\section{Mills Kaviar}

$32 \mathrm{kr}$

Eksempel 12: Matematikk, 4. trinn

\section{Engelsk}

På 30 av 42 ukeprøver spørres det om engelske ord og uttrykksmåter. Engelskspørsmåla står ofte tidlig på prøva, som nummer to eller tre. På enkelte ukeprøver i materialet gis det nivådelte oppgaver. Den dominerende oppgavetypen er gloseprøva, som forekommer på totalt 23 ukeprøver. Denne oppgavetypen har tett sammenheng med den korresponderende ukeplanen, hvor de engelske glosene er oppført sammen med ei oppfordring om å øve på dem heile uka. Antall gloser varierer en del, og ligger i spennet mellom fire og ni. Gloseprøva er satt opp på ulike måter. Det vanligste er at noen gloser står på engelsk og skal oversettes til norsk, mens de øvrige står på norsk og skal oversettes til engelsk. Enkelteksempler der alle de oppførte orda er skrevet på norsk og skal oversettes til engelsk, forekommer også. De yngste elevene skal 
koble sammen et engelsk ord med det korresponderende norske ordet. På enkelte ukeprøver finner vi oppgaver der eleven skal oversette ei eller flere engelske setninger til norsk.

Blant andre oppgaver kan nevnes skriveoppgaver, grammatikkoppgaver og samfunnsrelaterte oppgaver. I noen tilfeller etterfølges gloseprøva av ei skriveoppgave der elevene skal skrive et visst antall setninger der to eller flere av glosene skal brukes, som i eksempel 13. Flere oppgaver har grammatikk som tema. Det dreier seg om å sette inn was eller were i setninger med åpne rom, eller det dreier seg om å lage oversikter som viser bøyingsformene av substantiv, som i eksempel 14. Spørsmål knytta til kunnskap om det engelske samfunnet er det få av i materialet; i eksempel 6 vises en slik forekomst.

Skriv 2 setningar der du brukar 2 av glosene/ skriv 2 setninger der du bruker 2 av glosene.

Eksempel 13: Engelsk, 4. trinn 


\begin{tabular}{|c|c|c|c|c|}
\hline \multirow[t]{6}{*}{ Engelsk } & \multicolumn{4}{|c|}{$\begin{array}{l}\text { 1. Strek under substantivene: } \\
\text { dog - red - when - door - jump - desk - nice - } \\
\text { face - on - knife - if - black - write - school } \\
\text { 2. Step 1: Bøy substantivene som vist i eksemplet: }\end{array}$} \\
\hline & \multicolumn{2}{|c|}{ ENTALL } & \multicolumn{2}{|c|}{ FLERTALL } \\
\hline & a boy & the boy & boys & the boys \\
\hline & a cat & & & \\
\hline & a sister & & & \\
\hline & a house & & & \\
\hline
\end{tabular}

Eksempel 14: Engelsk, 5. trinn

De aller fleste engelskspørsmåla er lukka. Når det gjelder den samfunnsrelaterte oppgava, gloseprøvene og grammatikkoppgavene, er svara enten rette eller gale, og oppgavene åpner sannsynligvis ikke for alternative svar. Skriveoppgava i eksempel 13 er åpen, idet elevene kan velge tema å skrive om. De skal bare passe på å få inn to av ukas gloser.

Når det gjelder modalitetsbruken i engelskoppgavene i materialet, preges den av mange fellestrekk. Gloseprøva skal som regel skrives inn i tabellform. Det samme gjelder noen av grammatikkoppgavene. Andre oppgaver er satt i rammer, gjerne med ei eller flere stipla linjer som indikerer hvor omfattende svar som forventes. På ei prøve der de britiske «statene» skal navngis (eksempel 6), utnyttes et bestemt multimodalt samspill. Dette er eneste forekomst av bilde- og fargebruk i engelskfaglige spørsmål.

\section{Naturfag}

Naturfaglige spørsmål finner vi bare på 9 av de 42 ukeprøvene. Disse spørsmåla kommer gjerne etter spørsmåla i norsk, matematikk og engelsk, og elevene skal som regel ikke skrive lange svar. På noen ukeprøver er naturfag integrert i ordforklaringsoppgaver, der elevene på 4. trinn blant anna skal forklare ordbankorda «savanne» og «nasjonalpark». Andre oppgaver 
etterspør gjerne konkrete fakta, som «Skriv tre fakta om fjellreven» (på 4 . trinn). I andre tilfeller skal elevene vise at de kan koble navn på levende organismer til riktig bilde. I ukeprøver for 5. trinn finner vi begrepsrelaterte oppgaver, som når elevene skal bruke fagbegrep i relevante setninger eller sette navn på ulike deler av hjertet, og forklaringsoppgaver. I eksempel 15 ser vi ei todelt oppgave som ber om både ei faktaopplysning og ei forklaring.

Naturfag: Svar på spørsmålene.

A. Hvor mange bein har en edderkopp?

B.Hvorfor henger ikke edderkoppen fast i nettet sitt?

Eksempel 15: Naturfag, 5. trinn

Vi finner altså både lukka og åpne naturfaglige spørsmål. Det fins bare ett riktig svar på spørsmål A i eksempel 15, mens oppgava som etterspør tre fakta om fjellreven, kan besvares på flere måter. Forklaringsoppgavene inviterer elevene til å uttrykke seg med større sjølstendighet enn reine faktaoppgaver. De naturfaglige spørsmåla skal besvares på ulike måter, blant anna med ei tegning (på 3. trinn: «Tegn en næringskjede»), enkeltord (fagord), enkeltsetninger eller en lengre verbalspråklig tekst (på 5. trinn: «Forklar kva funksjon nyrene har»). I noen tilfeller er fotografier eller tegninger integrert i oppgava, men de fleste spørsmåla er uten illustrasjoner.

\section{Samfunnsfag}

Samfunnsfag er også representert på bare 9 av de 42 ukeprøvene. Disse spørsmåla kommer som regel etter spørsmåla i norsk, matematikk og engelsk. Noen av dem er kortsvarsoppgaver og handler blant anna om geografiske forhold i Norge og andre land (på 5. trinn). Her skal elevene blant anna skrive navnet på flest mulig fylker, og deretter plassere fem byer på norgeskartet. Disse oppgavene er lukka. Andre oppgaver inviterer elevene til å formulere seg 
sjølstendig, som på 4. trinn i oppgava: «Skriv og fortell hva du har lært om jernalderen». Her er det satt av stor plass til svaret. På ukeprøvene for 5. trinn finner vi også slike åpne spørsmål med rikelig skriveplass, se eksempel 16. Også i samfunnsfag finner vi altså både lukka og åpne spørsmål. Når det gjelder utforminga, er den enkel og lite variert. Det brukes ikke farger eller illustrasjoner, men i ett tilfelle er et kart integrert i oppgava.

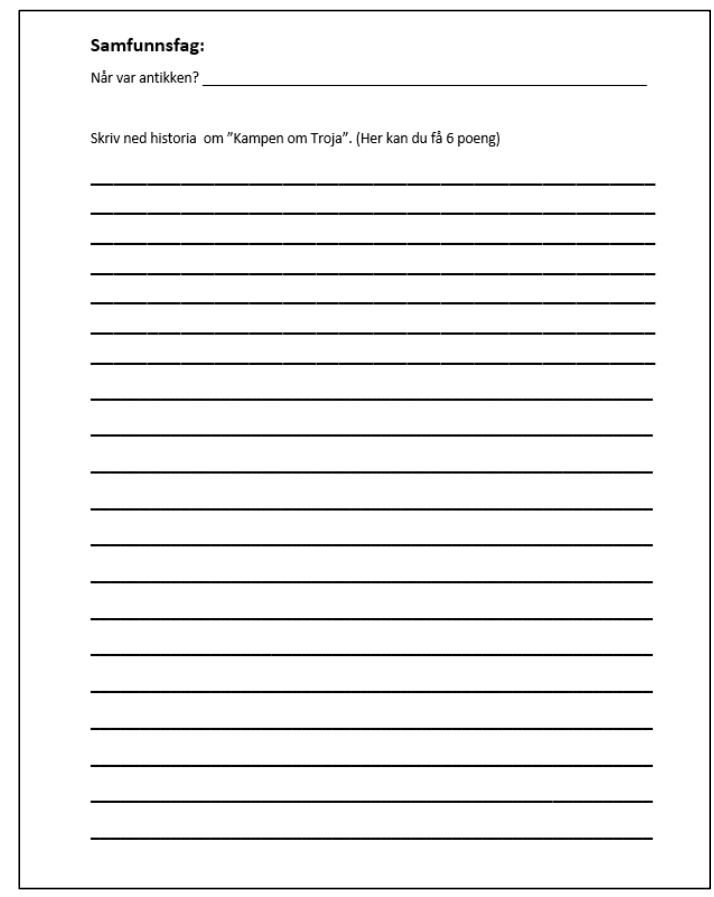

Eksempel 16: Samfunnsfag, 5. trinn

\section{Kristendom, religion, livssyn og etikk (KRLE)}

Spørsmål fra faget KRLE finner vi på bare 6 av de 42 ukeprøvene. Disse spørsmåla er plassert forskjellige steder på prøva, men aldri først. Det dreier seg om kortsvarsoppgaver, som nærmest kan omtales som utfyllingsoppgaver. I eksempel 17 gjengis ei oppgave som kombinerer lukka spørsmål med en mer åpen del med valgfrihet og noe rom for sjølstendig formulering. Også i dette 
faget finner vi både lukka og åpne spørsmål. Når det gjelder utforminga, brukes det ingen illustrasjoner eller farger.

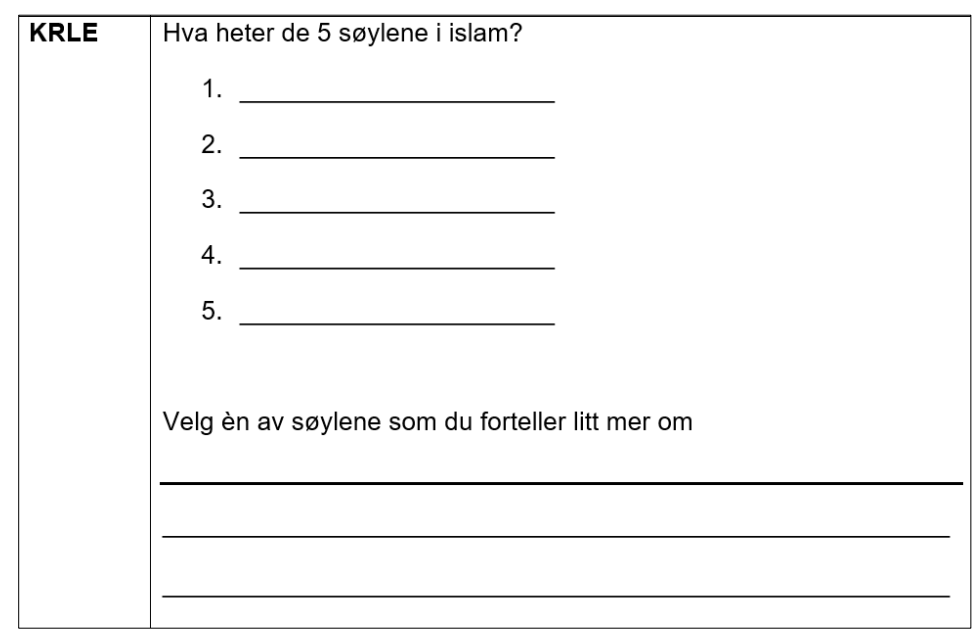

Eksempel 17: KRLE, 5. trinn

\section{Flerfaglige oppgaver}

Noen ukeprøver har med flerfaglige oppgaver. Det dreier seg om oppgaver som kombinerer elementer fra flere fag. Ei oppgave på 5. trinn handler om Lisa som er i London. Her må elevene forholde seg til noe engelskspråklig tekst for å kunne svare på matematikkspørsmål. Mer vanlige eksempler på flerfaglige oppgaver er ordforklaringsoppgavene. I eksempel 18 er faga norsk, naturfag og KRLE representert. Oppgava er en kombinasjon av lukka spørsmål der eleven skal fylle inn manglende ordbankord, og mer åpne spørsmål der eleven får mulighet til friere formulering av manglende ordforklaringer. I ordforklaringsoppgavene brukes ikke farger eller bilder. 


\begin{tabular}{|l|l|}
\hline ORDBANKORD & ORDFORKLARING \\
\hline Det skuespillerne skal gjøre skriver vi ofte i .. \\
\hline kjøtteter & \\
\hline Gyldne regel & \\
\hline miljøvern & \begin{tabular}{l} 
A gjøre en tekst om til et skuespill \\
\hline \\
\end{tabular} \\
\hline & $\begin{array}{l}\text { Passe på at miljø der planter og dyr lever, } \\
\text { ikke blir ødelagt. }\end{array}$ \\
\hline
\end{tabular}

Eksempel 18: Flerfaglig oppgave, 4. klasse

Eksempel 19 viser ei oppgave med fagovergripende innhold. Her skal elevene lese en lengre sammensatt tekst og svare på spørsmål som særlig vil vise ferdighet i å finne informasjon i teksten, men også spørsmål som i noen grad vil vise elevenes tolkings- og vurderingsferdighet. Slike oppgaver minner om nasjonale prøver i lesing og kan ha som formål å forberede elevene til denne prøva, eller de kan gi nødvendig trening etter denne. 


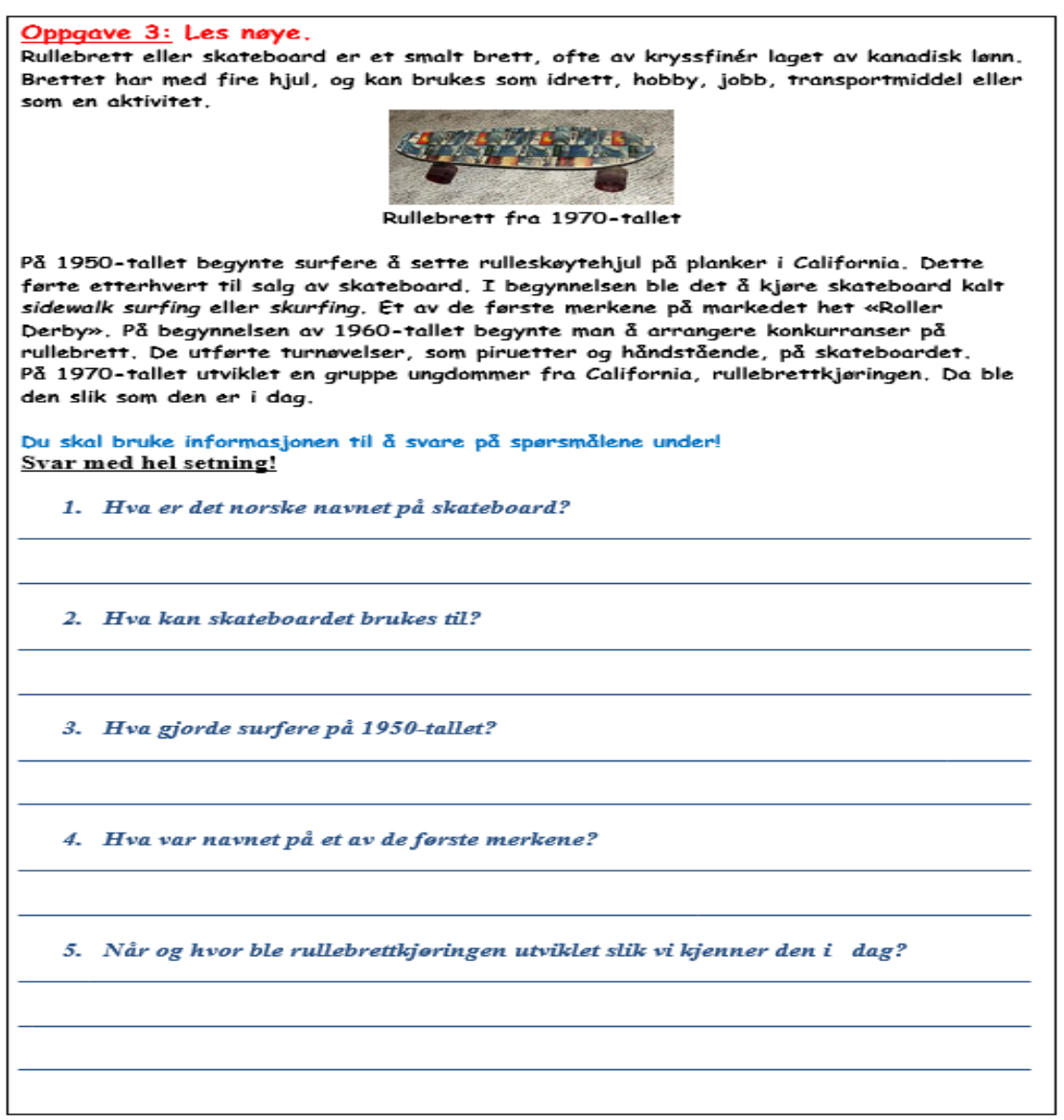

Eksempel 19: Oppgave med fagovergripende innhold, 5. trinn

\section{Overordna funn i fagoppgavene}

Gjennomgangen av de ulike faga i ukeprøvene ovafor kan sammenfattes ved å presentere enkelte overordna funn. Materialet viser tydelig at det er de tre store, skriftlige faga som dominerer i ukeprøvene. Det er derfor naturlig å se nærmere på norsk, matematikk og engelsk.

De norskfaglige oppgavene domineres av diktatoppgaver. Disse oppgavene er tett knytta til øveord på ukeplanen, og denne oppgavetypen har en svært tydelig kontrollfunksjon. Heilt tilsvarende finner vi gloseprøven som den vanligste oppgavetypen i engelsk, også denne med en klar kontrollfunksjon. Begge disse oppgavetypene er enkle å rette, og elevenes resultater er enkle å 
formidle til heimen. Det samme gjelder også for de mange matematikkoppgavene hvor elevene skal vise sine ferdigheter i de fire regneartene.

Slik sett er hovedinntrykket av oppgavene i de store faga at de kontrollerer raskt målbar kunnskap og ferdighet, som ordkunnskap eller regneferdighet. I de andre faga som er representert i ukeprøvene, er det langt færre oppgaver i materialet, og det er dermed færre tydelige tendenser, men vi finner noe større variasjon i disse oppgavene.

\section{Ukeprøva som del av skolens vurderingsarbeid}

I presentasjonen av karakteristiske trekk ved de 42 ukeprøvene i materialet legges det vekt på både fellestrekk og ulikheter. Vi ser at variasjonen er ganske stor når det gjelder formmessige og innholdsmessige forhold. Når vi undersøker hvilken funksjon spørsmåla har, ser vi at prøvene preges av langt mindre variasjon. De fleste fagspørsmåla må betegnes som kortsvarsoppgaver siden det jevnt over er avsatt liten plass til svaret. De er også ganske lukka og har en tydelig kontrollfunksjon. Det er i hovedsak faktaspørsmål elevene skal svare på, og som regel er derfor plassen til svar svært begrensa. Gjennom svar på for eksempel norskfaglige spørsmål skal elevene vise hva de sitter igjen med av faktakunnskaper og rettskrivingsferdigheter etter ukas arbeid med faget, men uten særlig plass og mulighet til sjølstendig skriving. Elevene skal svare på spørsmål gjennom fargemarkering, understreking og skriving av enkeltord eller ei setning, men de utfordres i liten grad til å utdype læringsutbyttet gjennom å skrive fortellende, beskrivende, reflekterende eller argumenterende svar. I samfunnsfag ser vi enkelte hederlige unntak fra dette hovedinntrykket siden det i noen tilfeller er avsatt god plass til å svare. Når det gjelder oppgaver med fagovergripende innhold, skiller de seg ut på en annen måte ved at de stiller spørsmål som elevene skal finne svar på i teksten som står på prøvearket, eller som de kan tolke ut av teksten. 
Ser vi på ukeprøva i lys av de tre danningsideala (Båtnes, 1995), er resultata tydelige. Svært mange spørsmål har klar sammenheng med det formative dannings- og kunnskapsidealet. Det gjelder for eksempel norskfagets orddiktater, engelskfagets gloseprøver og innfyllingsoppgaver i grammatikk, og matematikkens ferdig oppsatte regnestykker og oppgaver i gangetabellen. I svara på slike spørsmål skal elevene vise at de har automatisert faglige ferdigheter av ulike slag. Mange spørsmål reflekterer det figurative danningsog kunnskapsidealet. Her er begrepsorienterte oppgaver i ulike fag typiske eksempler, likeså de flerfaglige ordforklaringsoppgavene. Andre eksempler er naturfagets faktaspørsmål om fjellreven, og samfunnsfagets spørsmål om antikken. I svara på slike spørsmål skal elevene vise at de har arbeidd med skriftlig informasjon og kan forholde seg til fagbegrepa de har møtt i lærestoffet. Det operative dannings- og kunnskapsidealet er imidlertid ikke representert i ukeprøvene. Dette viser at ukeprøvas fremste formål er kontroll, ikke sjølstendig faglig vurdering og refleksjon.

Hvilken betydning har så denne teksttypen som del av skolens vurderingsarbeid? Gjennom ukeprøva får elevene mulighet til å vise hva de har fått med seg av konkrete kunnskaper og ferdigheter i skolefaga. Da fungerer ukeprøva som en dokumentasjon av elevenes faglige læringsutbytte, slik Duesund (2011) også framhever. Videre etterspør en del ukeprøver, ukeprøvetype 3, også informasjon om elevenes skolehverdag og om deres vurdering av egen læring og arbeidsinnsats. Det kan være nyttig for elevene å reflektere over egen rolle i skolehverdagen og å øve seg i å vurdere seg sjøl. Svara elevene gir på disse spørsmåla, kan gi læreren et dokumentert grunnlag for videre arbeid i rollen som sosiallærer og veileder. Siden mange lærere praktiserer at foresatte skal skrive under på at de har sett elevenes ukeprøve, inngår denne i samarbeidet mellom skolen og heimen og kan gi innsikt i elevenes utvikling, både faglig og sosialt. Slik ser vi at en del ukeprøver altså tilbyr en kontaktarena mellom lærer, elev og heim. 
Hva er så den egentlige verdien av dette? Noen lærere vil peke på at ukeprøvene inngår i ei nødvendig strukturering av skolearbeidet for mange elever, der en arbeider planmessig og systematisk ut fra definerte læringsmål for å oppnå et tydelig læringsutbytte. Her kan ukeprøvene inngå i vurdering $a v$ og for læring, avhengig av åssen de brukes i læringsarbeidet og i kommunikasjonen mellom lærer og elev og mellom lærer og foresatte. Faren er naturligvis at testinga får en for dominerende plass i undervisninga, slik at det nærmer seg vurdering som læring, slik Torrance (2007) advarer mot. Vårt materiale har også tydelige trekk som peker mot at ukeprøvene fokuserer på kunnskaper og ferdigheter som kan kontrolleres raskt og effektivt. Det vil kunne være svært uheldig uten bevisste lærere.

\section{Ukeprøva som del av samfunnsdebatten om skolen}

Hva skal Norge leve av etter olja? Kunnskap, svarer mange politikere. Vegard Kvam har kalt det overordna læringsmålet i Norge på 200o-tallet for «det kunnskapsrike menneske» (Kvam, 2016, s. 143), og videre pekt på vurdering for læring som det sentrale pedagogiske verktøyet. Men hvilket kunnskapssyn er ukeprøva som teksttype uttrykk for?

Gjennom ukeprøva får elevene i beste fall vist en overflatisk og oppstykka kunnskap, og i liten grad sammenheng og forståelse. Malkenes (2015) uttrykker skarp kritikk av det han oppfatter som en markedsstyrt skole som søker raske, målbare resultater, slik ukeprøva kan gi. Og da er vi ved det store spørsmålet som rett og slett dreier seg om hva slags grunnskole vi vil ha. Hvilke forventninger har vi til en god skole? Hvilke kunnskaper, ferdigheter og innsikter ønsker vi at elevene skal tilegne seg og utvikle i grunnskolen? Er ukeprøva et formålstjenlig verktøy i en god skole?

Det vil være lærernes bruk og forståelse av ukeprøva som avgjør om ukeprøva fortjener den plassen den har fått i skolen. Vårt materiale viser tydelig at 
ukeprøvene i stor grad tester kunnskapsfragmenter. En god skole bør vektlegge mer enn faktakunnskap i kortsvar. Slik sett virker ukeprøva som teksttype aleine å kunne gi et begrensa utbytte.

Gutten i innledninga, som døde litt innvendig før hver ukeprøve, er en elev som alle kan sympatisere med. Den bruken av ukeprøver som han opplever, er verken akseptabel eller fruktbar i læringsarbeidet. Gjennom denne studien meiner vi å ha avdekka at ukeprøva som teksttype har klare begrensninger. I tillegg har vi, som nevnt i redegjøringa for datainnsamlinga, erfart at ukeprøvene ofte er den enkelte lærers ansvar, og i liten grad inngår i skolens profesjonsfellesskap. Det kan virke som at ukeprøva som teksttype og tilhørende praksis bør synliggjøres og drøftes på skolene. Underveis i arbeidet med denne artikkelen har vi imidlertid snakka uformelt med flere lærere som er svært bevisste på åssen de bruker ukeprøvene, og hvilken rolle ukeprøvene har i undervisninga. Det er altså bruken og vektlegginga av ukeprøvene som vil avgjøre om de har ei framtid i skolen. Det avhenger fullt og heilt av i hvilken grad skoleledelse og lærere er bevisste brukere av teksttypen. Det må samfunnet kunne forvente. 


\section{Litteraturliste}

Baldry, A. \& Thibault, P.J. (2005). Multimodal transcription and text analysis. Sheffield: Equinox.

Birkenes kommune. (2015). Handlingsplan for Birkenesskolen 2014-2018. Henta fra http://www.birkenes.kommune.no/contentassets/7b2aab99506a4cf1a7c6fc3 335471d31/handlingsplan-for-birkenesskolen-2014-2018.pdf

Båtnes, P.I. (1995). En modell for lærebokstudiet: Lærebøkenes danningsidealer som normsettere for kunnskapsformidling. I E.B. Johnsen (red.), Virkelighetens forvaltere (s. 92-108). Oslo: Universitetsforlaget.

Duesund, C. (2011). Vurdering FOR læring. Presentasjon presentert på Samling for ressurspersoner i pulje 1, Vurdering for læring, Utdanningsdirektoratet Oslo. Henta fra https://www.udir.no/PageFiles/Vurdering\%2ofor\%2olaring/Dokumenter/Na sjonal\%20satsing/2/udir\%20\%20mai\%202011 .pdf

Dysthe, O. (2008). Klasseromsvurdering og læring. Bedre Skole, nr. 4, 2008, 16-23. Henta fra https://www.utdanningsnytt.no/globalassets/filer/pdf-avbedre-skole/2008/bedreskole-4-2008.pdf

Ertesvåg, F. (2015, 11. november). Skoleforsker: - Oslo-skolens prøveregime er angstfremkallende. Verdens Gang. Henta fra https://www.vg.no/nyheter/innenriks/skole-og-utdanning/skoleforsker-osloskolens-proeveregime-er-angstfremkallende/a/23558112/

Fylkesmannen i Buskerud. (2015). Endelig tilsynsrapport: Tilsyn med skolens arbeid med elevens utbytte av opplæringen Drammen kommune Hallermoen skole. Henta fra 
https://www.fylkesmannen.no/Documents/Dokument\%20FMBU/Tilsyn/OU/FNT_En delig\%20tilsynsynsrapport_Drammen\%20kommune_Hallermoen\%20skole.pdf

Hodgson, J., Rønning, W. \& Tomlinson, P. (2012). Sammenhengen mellom undervisning og læring: En studie av læreres praksis og deres tenkning under Kunnskapsløftet. Sluttrapport (NF-rapport 4/2012). Henta fra https://www.udir.no/Upload/Rapporter/2012/SMUL.pdf

Hodgson, J., Rønning, W., Skogvold, A.S. \& Tomlinson, P. (2010). Vurdering under Kunnskapsløftet: Læreres begrepsforståelse og deres rapporterte og faktiske praksis (NF-rapport 17/2010). Henta fra http://www.nordlandsforskning.no/getfile.php/132565/Dokumenter/Rapporter/2010/R apport_17_2010.pdf

Kvam, V. (2016). Jakten på den gode skole: Utdanningshistorie for lærere. Oslo: Universitetsforlaget.

Malkenes, S. (2015, 6. august). Styringen av Osloskolen er gammeldags. Dagbladet. Henta fra https://www.dagbladet.no/kultur/styringen-av-osloskolen-ergammeldags/60176604

Nohre-Walldéns, G. (2013, 27. juni). «Han hvisker i øret til pappaen sin hver torsdag kveld at han dør i magen fordi han skal uketestes i morgen». Aftenposten. Henta fra https://www.aftenposten.no/meninger/kronikk/i/XwXpo/Han-hvisker-i-oret-tilpappaen-sin-hver-torsdag-kveld-at-han-dor-i-magen-fordi-han-skal-uketestes-i$\underline{\text { morgen }}$

Roen, G. (2015). Begrepene i naturfag: Hvordan arbeider lærere med naturfaglige begreper gjennom dialog, lesing og skriving for å legge til rette 
for elevenes forståelse av naturfagtekster? (mastergradsavhandling, Universitetet i Oslo). Henta fra https://www.duo.uio.no/handle/10852/45671

Sandvik, L.V., Engvik, G., Fjørtoft, H., Langseth, I.D., Aaslid, B.E., Mordal, S. \& Buland T. (2012). Vurdering i skolen: Intensjoner og forståelser: Delrapport 1 fra prosjektet Forskning på individuell vurdering i skolen (FIVIS). Henta fra https://www.udir.no/Upload/Rapporter/2012/fivis.pdf?epslanguage=no

Sandvik, L.V. \& Buland, T. (red.). (2013). Vurdering i skolen:

Operasjonaliseringer og praksiser. Delrapport 2 fra prosjektet Forskning på individuell vurdering i skolen (FIVIS). Henta fra https://www.udir.no/Upload/Rapporter/2013/FIVIS2.pdf?epslanguage=no

Sandvik, L.V. \& Buland, T. (red.). (2014). Vurdering i skolen: Utvikling av kompetanse og fellesskap. Sluttrapport fra prosjektet Forskning på individuell vurdering i skolen (FIVIS). Henta fra https://www.ntnu.no/documents/1272526547/1272693899/FIVIS+sluttrapport+2014. pdf/12c3ed39-d86c-424f-af37-88b5ff5e8ee2

Sivesind, K. (2013). Læreplanene i Kunnskapsløftet: Et internasjonalt sammenliknende perspektiv. Norsk Pedagogisk Tidsskrift, 97(6), 370-387. Henta fra https://www.idunn.no/file/pdf/63968186/npt_2013_06_pdf.pdf

Sjøberg, S. (red.). (2001). Fagdebatikk: Fagdidaktisk innføring i sentrale skolefag. Oslo: Gyldendal Akademisk.

Skrede, J. (2017). Kritisk diskursanalyse. Oslo: Cappelen Damm Akademisk.

Smidt, J. (2010). Skriving i alle fag - innsyn og utspill. Trondheim: Tapir Akademisk. 
Torrance, H. (2007). Assessment as learning: How the use of explicit learning objectives, assessment criteria and feedback in post-secondary education and training can come to dominate learning. Assessment in Education, 14(3), 281294. doi: $\underline{10.1080 / 09695940701591867}$ 